\title{
Introduction to the Special Issue on: The Reception of the Church Fathers and Early Church Historians in the Renaissance and the Reformation, c. 1470-1650
}

\author{
Andreas Ammann ${ }^{1}$. Sam Kennerley ${ }^{2}$
}

Published online: 2 December 2019

(c) Springer Nature B.V. 2019

As Beatus Rhenanus, undoubtedly one of the greatest promoters of patristic scholarship in the early modern period, wrote in the preface to his 1523 collection of church historians: 'One could certainly wonder why the writers of ecclesiastical history ... are being neglected as if they weren't worthy of being taken in hand.' ${ }^{1}$ Until recently, one could with equal astonishment ask why modern researchers have largely ignored the enthusiasm for the Church Fathers and early church historians that was instigated in the fifteenth and sixteenth century by such figures as Ambrogio Traversari, Beatus Rhenanus, Erasmus of Rotterdam and a great many similar-minded scholars. The age of Renaissance and Reformation, it is increasingly recognized, was marked not only by a new era in the reception of classical antiquity, but also the beginning of 'nearly three centuries of unprecedented developments' in the field of patristics. ${ }^{2}$ In this period, well-known Church Fathers were disseminated in new, ground-breaking editions, many hitherto lost Greek church authors were rediscovered and made available in the original language or in translation, and patristic texts were closely read by the many, often feuding, confessional groups who sought answers to the questions that had been raised by contemporary debates about the past and present of the church.

Yet, for a long time, this preoccupation with patristic texts remained a topic merely touched upon in passing by scholars of the theological, historical and cultural

\footnotetext{
${ }^{1}$ Autores historiae ecclesiasticae, Basel, 1523, fol. aa3 ${ }^{\mathrm{r}}$ : iure mirari quis possit, quur Autores ecclesiasticae historiae ... ita apud nos neglecti iaceant, velut indigni qui habeantur in manibus. On Rhenanus and his edition, see Anthony Grafton's article in this special issue.

2 I. Backus, 'The Fathers and the Reformation', in The Wiley Blackwell Companion to Patristics, ed. K. Parry, Chichester, 2015, pp. 428-41 (429).
}

Andreas Ammann

andreas.ammann@thesaurus.badw.de

Sam Kennerley

sjk76@cam.ac.uk

1 Thesaurus linguae Latinae, Bayerische Akademie der Wissenschaften, 80539 München, Germany

2 Peterhouse, Cambridge CB2 1RD, UK 
developments of the early modern period. It was not until a rise of interest in the history of scholarship and religion in the 1970s that the importance of the subject started to be recognized. ${ }^{3}$ Since then, an ever-growing number of studies has been devoted to the reception of the Church Fathers and early church historians, allowing us to better understand how early modern theologians and humanists debated Christianity's ancient roots through its earliest intellectuals. While there is still no book-length treatment of patristic reception in the early modern period, companions and bibliographies provide much-needed overviews and guides to a growing body of secondary literature. ${ }^{4}$ Besides these publications, a selection of edited volumes serve as the most useful introductions to the latest developments in the field. ${ }^{5}$

The present special issue is a contribution to this literature on the reception of the Church Fathers and early church historians. The articles published here are split into three groups, the first of which explores patristic reception across broad swathes of time. In the opening article of this special issue, Natasha Constantinidou exploits quantitative data from the Universal Short Title Catalogue and the Verzeichnis der im deutschen Sprachbereich erschienenen Drucke des 16. Jahrhunderts to highlight major trends in the printing of the Greek Church Fathers between c.1450 and 1600. Constantinidou finds that a small group of authors - Basil of Caesarea, Gregory Nazianzen, Eusebius of Caesarea, but above all John Chrysostom - dominated the printing of the Greek Church Fathers in this period, sometimes outstripping classical writers in the number of editions. Constantinidou also points to the predominance of Latin as the language of early modern scholarship on the Greek fathers, and the gradual rise of Paris as a centre for patristic publishing in the sixteenth century. Nonetheless, readers might find most striking the connection drawn in this article between patristic texts, religiously diverse printing centres, and the teaching of Greek, since this approach suggests ways of understanding early modern editions of the Fathers that avoid the present historiographical emphasis on confession.

Jean-Louis Quantin expands this history of patristic printing into the later years of the early modern period, beginning with a reconstruction of the cat-andmouse world of the press. As censorship came into greater force, printers devised new ways to ensure that their editions of the Church Fathers could be sold on a

\footnotetext{
3 Seminal in this regard is C. L. Stinger, Humanism and the Church Fathers: Ambrogio Traversari (1386-1439) and Christian Antiquity in the Italian Renaissance, Albany, 1977.

${ }^{4}$ For a survey of the essential literature on patristics in the early modern period, see S. Kennerley, 'The Church Fathers in Renaissance and Reformation Thought', in Oxford Bibliographies Online: Renaissance and Reformation (<https://www.oxfordbibliographies.com/view/document/obo-9780195399301/ obo-9780195399301-0384.xml>). For a recent overview of the topic, see I. Backus, 'Patristics', in Brill's Encyclopaedia of the Neo-Latin World: Macropaedia, ed. Ph. Ford, J. Bloemendal, and Ch. Fantazzi, pp. 733-745, Leiden, 2014; Backus, 'The Fathers and the Reformation' (n. 2 above), pp. 428-41.

5 See, e.g., The Reception of the Church Fathers in the West: From the Carolingians to the Maurists, ed. I. Backus, 2 vols., Leiden, 1997; Die Patristik in der frühen Neuzeit: Die Relektüre der Kirchenväter in den Wissenschaften des 15. bis 18. Jahrhunderts, ed. G. Frank, T. Leinkauf and M. Wreidt, Stuttgart, 2006; I padri sotto il torchio: Le edizioni dell'antichità cristiana nei secoli XV-XVI, ed. M. Cortesi, Florence, 2002; Sacred History: Uses of the Christian Past in the Renaissance World, ed. K. Van Liere, S. Ditchfield, and H. Louthan, Oxford, 2012. For further references, see Kennerley, 'The Church Fathers' (n. 3 above).
} 
multi-confessional market. The result of these tricks was a hermeneutic of suspicion, wherein readers and inquisitors subjected patristic editions to occasionally embarrassing attention. Although its utility in the early modern period was mixed, Quantin shows us that historians might profit from applying this way of reading to early modern editions of the Church Fathers. A powerful case is made not to rely on prefaces to patristic editions when writing a history of scholarship, as their bold claims can obscure what prove on examination to be derivative or even pirated texts. Some past scholarship comes out considerably worse for wear after this erudite analysis, and our mental map of patristic printing changes too. Quantin introduces us to neglected peripheries of the republic of letters, whether small presses in the Holy Roman Empire and France, or libraries and scholars in Italy, England, and Spain. He also brings to light the relationship between these peripheries and major centres of scholarship in Europe. Like Constantinidou, Quantin finds that there was growing centralization of patristic printing in Paris in the early modern period, culminating at the end of the seventeenth century with the near-monopoly exercised in this area by Parisian printers and their Maurist collaborators.

The third article of this special issue guides us through the reception of one church historian in the early modern period. As Anthony Grafton notes, Eusebius of Caesarea has become central to discussions of the history of historiography, a status achieved in no small part due to the work of Grafton and his mentor Arnaldo Momigliano. ${ }^{6}$ But while reasserting the continued relevance of Momigliano's conclusions about Eusebius, Grafton presents us with a more variegated image of this church historian. The Eusebius that we see here is not just the author of the Ecclesiastical History, whose extensive quotation of sources inspired the format of early modern histories like those of Baronio and Flacius. He is also the author of the Chronicle read by chronologists such as Heinrich Pantaleon and Arnaud de Pontac, and an author encountered not in Greek, but in the Latin translations of Jerome and Rufinus. Indeed, the Eusebius uncovered here is as much a mine as a model, whose sources proved to be as interesting to early modern scholars as the way that he used them. As an extended study of a key figure in Grafton and Momigliano's work, this article is an important contribution to scholarship on the nature and development of early modern historiography.

The articles in the second group focus our attention on specific case studies. Sam Kennerley's article reconstructs the history of a manuscript of John Chrysostom's Homilies on Romans held at the Herzog August Bibliothek in Wolfenbuittel, which was copied and used in the circle of Desiderius Erasmus. Based on Erasmus's letters and the annotations to this manuscript, Kennerley shows that this codex is the best surviving witness to Erasmus's copy of the Homilies on Romans, and the base

\footnotetext{
6 A. D. Momigliano, 'Pagan and Christian Historiography in the Fourth Century A.D.', in The Conflict Between Paganism and Christianity in the Fourth Century, ed. A. D. Momigliano, Oxford, 1963, pp. 79-99; A. T. Grafton, 'Church History in Early Modern Europe: Tradition and Innovation', in Sacred History (n. 4 above), pp. 3-26; A. T. Grafton, 'Arnaldo Momigliano and the Tradition of Ecclesiastical History', in The Legacy of Arnaldo Momigliano, ed. T. Cornell and O. Murray, London and Turin, 2014, pp. 53-76. Grafton recounts his time with Momigliano most vividly in A. T. Grafton, Defenders of the Text: The Traditions of Scholarship in an Age of Science, 1450-1800, Cambridge MA, 1991, pp. 5-10.
} 
text for Germain de Brie's Latin translation of this work. This identification supports a discussion of the scholarly practices of de Brie and Erasmus, with potentially surprising results. Although good friends, we see that de Brie and Erasmus made little use of one another's scholarship. Moreover, we find that Erasmus's reading of Chrysostom was at times tendentious, advancing a specific theology of free will and grace over fidelity to textual criticism.

Desiderius Erasmus proves similarly important to Madeline McMahon's article on the English prelate and scholar John Jewel. As McMahon shows, humanists from Poggio Bracciolini to Erasmus established a reading of the patristic past that noted discord as well as consensus in the ancient church. Jewel made ample use of this argument from history to defend the Church of England against charges of schism levelled by his Catholic opponents. Yet in this article, we see that hermeneutics proved just as important as history in the shaping of Reformation polemics about the ancient church. Based on a close analysis of Jewel's copy of the Erasmian Jerome, McMahon shows that Jewel followed Erasmus in reading patristic texts as a collection of commonplaces. For all their disagreements over history, we see that this hermeneutic was practiced by Jewel as well as his adversaries like Thomas Harding. The result of this commonplacing approach was the reduction of patristic texts to an irreconcilable mass of statements at once authoritative, and yet open to all manner of interpretation, a hermeneutic that stoked feuds among sixteenth-century theologians as much as it fragmented their visions of the patristic past.

Andrew Taylor's article draws our focus from England to northern Italy. Through a study of sixteenth-century manuscripts of Photius, Cyril of Alexandria, and Theodoret of Cyrus, Taylor reconstructs the existence of a network of Catholic scholars involved in the discovery and dissemination of texts of the Greek Church Fathers during the 1540s. Joining figures from the Italian peninsula like Marcello Cervini and Guglielmo Sirleto, French collectors like Antoine Perrenot de Granvelle and Guillaume Pellicier, the Spanish bibliophile Diego Hurtado de Mendoza, and the German banker Hans Jakob Fugger, Taylor shows that this network's interests in the fathers were as various as their origins. While some members of the network collected manuscripts of the fathers as part of their desire to assemble a universal library, for instance, others gathered patristic texts for use in the debates at the Council of Trent.

As he notes in his conclusion, Taylor has identified a huge range of sources and topics that await further study. This is also true of the direction pursued in the final set of articles in this special issue. To date, most studies of the reception of the Church Fathers have concentrated on Western Europe. The articles in third group of this special issue instead turn their focus east, bringing to the fore the patristic scholarship of early modern Greeks.

Nil Palabıy1k's article paints in vivid colours the scholarly and political background to a debate about Cyril of Alexandria held in Istanbul in 1627, which led to the expulsion of the Jesuits from the Ottoman Empire. After a series of philoCatholic patriarchs in the early seventeenth century, some clergy in Istanbul cultivated links with Protestant powers to counteract the growing influence of the Jesuits and the Propaganda fide. A key part of this programme was the establishment of a Greek press in London under the supervision of the Orthodox monk Nicholas 
Metaxas. As Palabiyık shows, Metaxas's publication of a series of Greek tracts on the procession of the Holy Spirit, and the consequent import of these books into the Ottoman Empire with English assistance the following year, was the ultimate cause of the fateful debate of 1627. As well as drawing attention to neglected themes like early modern Greek interpretations of the Greek Church Fathers, this article benefits from a series of impressive discoveries, not least a copy of Gennadios Scholarios's tract on the procession of the Holy Spirit with corrections in the hand of this fifteenth-century patriarch, which Palabiyık demonstrates was used as the base for the 1626 edition.

An inescapable figure in Palabıyık's article is Cyril Lucaris, the patriarch of Constantinople whose apparently 'Calvinist' confession of faith was published in Geneva in 1629. Lucaris's confession prompted joy among Protestants, concern among Catholics, and has been a source of contention for historians since. One undeniable point is that Lucaris's confession was a major factor in his murder by the Ottoman authorities in 1638. The next article in this special issue explores the relations between Greek and Latin Christians in the wake of Lucaris's downfall. Sundar Henny pieces together the life of Nathanael of Leucas, a Greek archbishop who from 1638 to his death in 1661 wandered from Vienna to Paris, via Sweden and Switzerland. Focusing primarily on Nathanael's encounters with Heinrich Hottinger and Jacques Goar, Henny shows how Nathanael was interviewed by Western scholars who hoped that this Greek prelate might prove a valuable source for the history of the ancient church. Henny finds that Nathanael's Protestant hosts were mainly interested in patristics, and Catholics in the liturgy, but the article never loses sight of what the surviving paper trail might tell us about Nathanael's side of the story.

In the final article in this special issue, Cornel Zwierlein brings to our attention the remarkable attempts by English non-jurors to form a union with the Greek Orthodox church between 1716 and 1725. Zwierlein first builds up the theoretical foundations of this exchange, demonstrating that non-jurors like Henry Dodwell and Charles Leslie used their reading of the letters of Clement, Ignatius, Polycarp, and especially Cyprian to formulate a distinctive ecclesiology that argued churches were free to conduct diplomacy independent of papal or state control. Zwierlein then shows us how this theory was put into practice in the negotiations for union carried out between 1716 and 1725, uncovering in the process some fascinating details. On the one hand, we learn that in order to obtain union, English non-jurors were willing to drop the filioque and to devise a liturgy that would be used jointly by Anglican and Greek congregations. On the other, we see that the Greeks insisted that the Anglican church submit to the patriarch of Jerusalem, and follow a definition of orthodoxy defined on Greek terms. Besides the limited ability of non-jurors to carry through these plans in practice, Zwierlein concludes that these discussions failed partly due to intervention by the English crown and state church, and partly due to an unresolved tension between the ecclesiologies of the non-juror and Greek participants in the exchange.

The articles in this special issue therefore travel from the invention of print to the early eighteenth century, and traverse the map from Spain to the Levant. They thereby demonstrate the extraordinary scope and potential of research about patristic reception, not least in the avenues for future research that they suggest. While the 
final three articles hint at the prospects of research about the patristic scholarship of the eastern churches, the first six indicate that research can still change our preconceptions about well-known Western figures. In spatial terms, one potential area for research not represented in this special issue is the Americas, which is becoming a focus for research in the associated fields of classical and biblical scholarship. ${ }^{7}$

This special issue prints selected papers from the conference 'The Reception of the Church Fathers and Early Church Historians, c. 1470-1650', held at Trinity College, Cambridge, in September 2016, augmented by the contributions of Constantinidou and Palabiyik. This event unintentionally became the second instalment in what is as yet a trilogy of workshops and conferences held at Trinity College about the early modern scholarship on the Christian past, following a conference organized in 2013 by Nicholas Hardy and Dmitri Levitin, and followed by another organized in 2019 by Eloise Davies, Tom Langley, and Odile Panetta. Our workshop was made possible by the generous support of the Faculty of History, University of Cambridge, and the Faculty of Humanities, University of Bern. The editors of this volume would like to express their gratitude to Kirsten Macfarlane who, as part of the organizing committee, greatly contributed to the success of the event, and to Scott Mandelbrote and Emily Michelson for their advice about the future of this collection after the conference. We are also indebted to the anonymous reviewers of the IJCT for their insightful comments, and to Jill Kraye for the opportunity to publish our proceedings in this journal.

Publisher's Note Springer Nature remains neutral with regard to jurisdictional claims in published maps and institutional affiliations.

\footnotetext{
${ }^{7}$ For the former, see for instance Antiquities and Classical Traditions in Latin America, ed. A. Laird and N. Miller, Chichester, 2018; for the latter, see K. Macfarlane's forthcoming Amateur Divines: Lay Learning and the Bible in Seventeenth-Century England and New England. A.-S. Schäfer, Auctoritas Patrum? The Reception of the Church Fathers in Puritanism, Frankfurt, 2012 represents a first forray into the subject of patristic reception in colonial north America.
} 